\title{
sciendo

\section{Assessment of the Implementation of Sustainable Energy Action Plans at Local Level. Case Study of Latvia}

\author{
Anda JEKABSONE ${ }^{1 *}$, Agris KAMENDERS ${ }^{2}$, Marika ROSA $^{3}$, \\ Jan KASELOFSKY ${ }^{4}$, Ralf SCHULE ${ }^{5}$ \\ ${ }^{1-3}$ Institute of Energy Systems and Environment, Riga Technical University, \\ Azenes iela 12/1, Riga, LV-1048, Latvia \\ ${ }^{4,5}$ Wuppertal Institute for Climate, Environment and Energy, Doeppersberg 19, \\ Wuppertal, 42103, Germany
}

\begin{abstract}
The need for sustainable energy management at the municipal level is growing, in order to meet EU climate goals. Multiple initiatives have been launched to support municipalities in energy planning and strategy development process. Despite available support, research shows mixed results about implementation of plans and strategies. This research paper analyses what targets municipalities set, how they monitor implementation of their sustainable energy action plans (SEAPs) and searches for the most important factors that have enabled or hindered the implementation of local SEAPs at Latvia. The article shows that, in some cases, there is evidence that SEAP development is a project-based activity, supported by external experts. From municipal personnel point of view, it is a project that ends with approved SEAP, but not a part of their future daily routine. Eventually implementation of the plan is difficult, because municipalities lack experience in daily management of energy data, distribution of responsibilities and implementation of procedures. Municipalities also tend to exclude important stakeholders in their SEAPs, like, private sector, household sector and transport sector, which lead to lower targets and lower achievements in GHG reduction.
\end{abstract}

Keywords - Energy management; energy planning; municipality; sustainable energy action plan

\section{INTRODUCTION}

By facing more and more climate change issues around the globe each year, the management of climate change has become major concern at European Union (EU) and scientific world [1]. On September $25^{\text {th }} 2015$, the UN General Assembly adopted The 2030 Agenda for Sustainable development, where 17 Sustainable Development Goals and 169 targets were defined [2]. By adopting this Universal Agenda, world leaders listed climate change as one of the priorities. In December 2015 at the Paris climate conference (Conference of Parties to the UN Framework Convention on Climate Change - COP21) 195 countries adopted a global climate deal, the so-called Paris Agreement, agreeing to keep the global average temperature rise below $2{ }^{\circ} \mathrm{C}$ [3]. In December 2018 at the UN climate change Conference of Parties (COP24) at Katowice, world leaders agreed on measures for implementing the Paris agreement. Shortly before COP24 at Katowice, the European Commission adopted a European strategic long-

\footnotetext{
${ }^{*}$ Corresponding author.

E-mail address: anda.jekabsone@edu.rtu.lv

(C)2019 Anda Jekabsone, Agris Kamenders, Marika Rosa, Jan Kaselofsky, Ralf Schule.

This is an open access article licensed under the Creative Commons Attribution License (http://creativecommons.org/

licenses/by/4.0), in the manner agreed with Sciendo.
} 
term vision for a prosperous, modern, competitive and climate neutral economy "A clean Planet for all" stating that Europe can be climate-neutral by 2050 [4].

Many argue that cities are the most important actors at reaching climate goals, as the urban areas are consuming roughly two thirds of global primary energy consumption [5], [6]. Although in countries like Latvia, where around a half of the population is living outside big cities, energy planning and energy management in rural areas is crucial for meeting climate goals. Rural municipalities face even more issues with sustainable energy planning, because of scattered and decreasing population density and lack of internal municipal funding. Often towns and villages are struggling with maintaining district heating (DH) systems, as many residential buildings start to use alternative heat sources or renovates the buildings (increasing energy efficiency) resulting in significantly lower heat consumption. Decreased heat demand from DH can result in increased specific heat losses and prices [7]. Bariss et al. has found that increasing income and resulting growth in energy consumption can be an impediment for reduction of energy consumption [8], especially when all the rural areas are determined to develop.

In 2008, the Covenant of Mayors (CoM) initiative was launched to provide support for local municipalities which volunteer to reduce greenhouse gas (GHG) emissions; since then 7755 municipalities, both big and small, have joined the initiative [9], [10]. CoM has been successful with inclusion of small cities, especially in countries that lack comprehensive national frameworks, by providing tools and knowledge for energy planning [11]. But still several problems of SEAP implementations have been indicated in literature. Researchers Ivner and Gustaffson indicated that, even if municipality do follow up their SEAP, most likely only implementation of actions will be monitored, but not the impact of those actions. They argue that energy issues have to become a natural part of daily work [12]. Kamenders et.al emphasize a lack of expertise among municipal personnel [13], while Melica et al., concluded that small cities can successfully participate in climate initiatives if support by Covenant Territorial Coordinators (CTC) are provided (expert organizations or local governments like regions or provinces). The research showed that $98 \%$ of all SEAPs submitted to CoM in Spain was developed with support from CTC, $93 \%$ in Belgium and $70 \%$ in Italy [11]. This shows the huge importance of external support for small municipalities.

The objective of this study is to analyse implementation of SEAPs in order to investigate if the approach of SEAPs is successful, what kind of targets have been set and how SEAPs have been monitored. As well, what are the most important factors that enabled or hindered the implementation of SEAPs. This study aims to increase knowledge of stakeholders (technical experts, energy managers, municipal officials and policy makers), so that they can make better decisions and design more effective procedures for reaching SEAP targets. Information have been collected through a survey in the form of a questionnaire, literature review and analyses of SEAPs.

\section{Methodology}

During this study an online in-depth questionnaire and SEAPs of all involved municipalities in Latvia were used. The study was organized under the framework of a H2020 funded project Compete4SECAP. The project Compete4SECAP aims at assisting local authorities to introduce an energy management system and initiate systematic implementation of climate mitigation and adaptation measures at the local level.

In Latvia there are 119 municipalities of which 110 are towns with rural areas or only rural areas and 9 are cities. Although only 15 municipalities have joined CoM, more than 40 local authorities have developed and approved their SEAPs. It is worth to notice that all SEAPs are 
developed with massive support from expert organizations and EU projects (like Conurbant, SEAP+, Meshartility, 50000\&1 SEAP, etc.). To collect the data used in this study, the municipalities (energy managers or person responsible for SEAP implementation) have been approached. From 42 municipalities, 11 agreed to answer an in-depth questionnaire about their SEAP and implementation process. Characteristics of municipalities included in this study are described in Table 1.

Questionnaire consisted of six parts - basic profile of the municipality, targets, data availability, SEAP implementation, monitoring and energy management system. Altogether 43 questions were included in the questionnaire. Collected data were complemented by information available from the approved SEAPs. Qualitative analysis was used to process and explain data. Structure of the questionnaire process is shown in Fig. 1.

For analysing the results, municipalities were divided in 4 groups based on population size - large municipality (>50 000 residents), medium municipality (30 000-50 000 residents), small municipality (10 000-30 000 residents), very small ( $<10000$ residents). Both large municipalities are cities and all others are towns with rural areas.

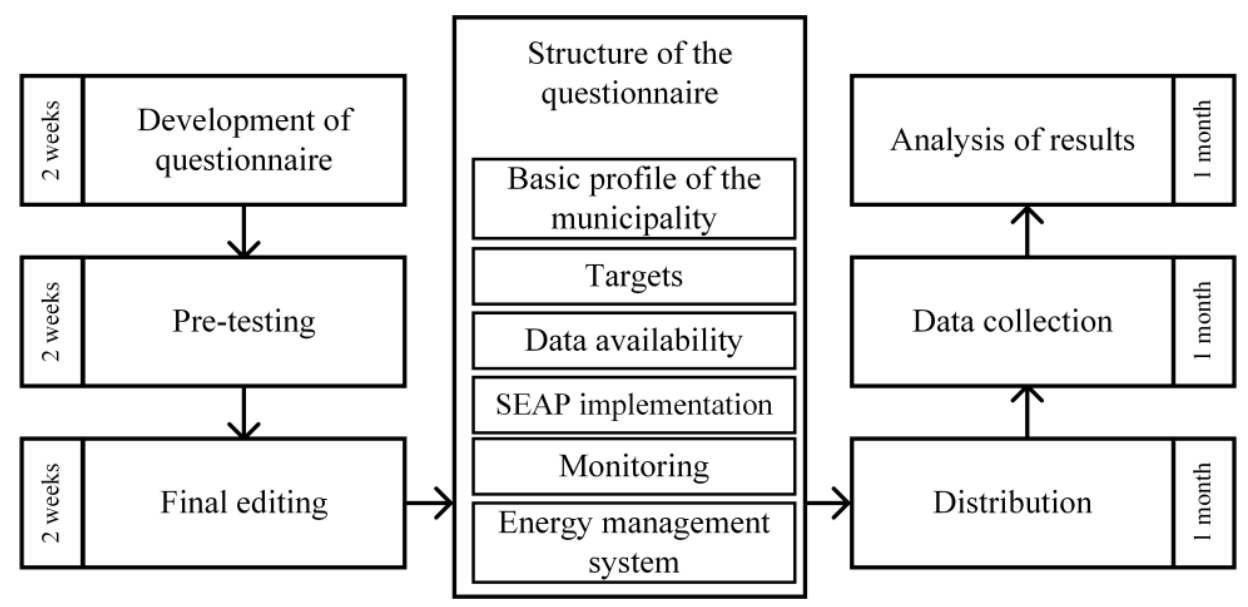

Fig. 1. Structure of the questionnaire process.

The period covered by SEAP varies among the 42 municipalities. All CoM signatories have developed their SEAPs before 2017 covering actions until 2020. Other municipalities have developed their SEAPs recently (in 2018) and the actions are planned until 2025. 
TABLE 1. CHARACTERISTICS OF MUNICIPALITIES

\begin{tabular}{llll}
\hline Municipality & Size of municipality & CoM Signatory & SEAP period \\
\hline A & Large & CoM & $2014-2020$ \\
B & Large & CoM & $2016-2020$ \\
C & Medium & CoM & $2013-2020$ \\
D & Medium & CoM & $2011-2020$ \\
E & Small & - & $2016-2020$ \\
F & Small & - & $2014-2020$ \\
G & Small & - & $2015-2020$ \\
H & Small & CoM & $2016-2020$ \\
J & Small & CoM & $2013-2020$ \\
K & Small & - & $2018-2025$ \\
L & Very small & CoM & $2013-2020$ \\
\hline
\end{tabular}

\section{RESUlts}

\subsection{Determined Targets at Municipalities}

As Table 2 shows, all municipalities have committed themselves to a general $\mathrm{CO}_{2}$ reduction target, and most of them have defined additional sector-specific targets. Both large and small municipalities set ambitious targets. The highest $\mathrm{CO}_{2}$ targets have been set by small municipalities, but at the same time the lowest targets also. None of the two medium-sized municipalities have any additional targets mentioned.

All municipalities setting additional targets mostly plan to reduce energy consumption in sectors directly managed by municipal bodies; other sectors are encouraged to reduce energy consumption, without taking responsibility for achieving goals. From those who have set sector specific targets, all have committed themselves to reduce energy consumption at buildings owned by the municipality, five of them have committed to reduce energy consumption in energy production sector, but only one has decided to reduce energy consumption in transport and public lighting sectors.

The targets in all municipalities but one is set until 2020, with the base year varying from 2000 to 2016. This is mainly due to the fact that after several territorial reforms, municipalities still struggle with the collection of reliable historical data. 
TABLE 2. DETERMined TARGETS AT SEAPs OF EACH MuniciPALITy

\begin{tabular}{|c|c|c|c|c|c|}
\hline \multicolumn{2}{|c|}{ Municipality } & \multirow{2}{*}{$\begin{array}{l}\mathrm{CO}_{2} \\
\text { saving, \% } \\
35\end{array}$} & \multirow{2}{*}{$\begin{array}{l}\begin{array}{l}\text { Target } \\
\text { year }\end{array} \\
2020\end{array}$} & \multirow{2}{*}{$\begin{array}{l}\text { Base } \\
\text { year }\end{array}$} & \multirow{2}{*}{ 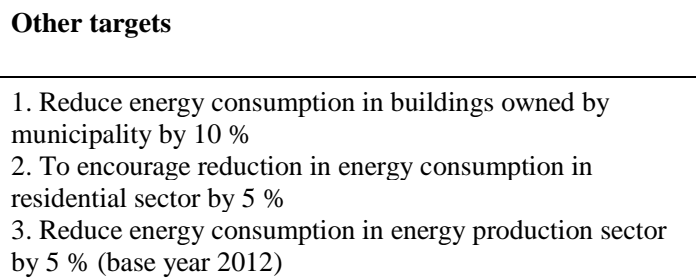 } \\
\hline Large & A & & & & \\
\hline Large & B & 10 & 2020 & 2010 & $\begin{array}{l}\text { 1. Reduce } \mathrm{CO}_{2} \text { emissions by } 40 \% \text { until } 2030 \\
\text { 2. Reduce energy consumption in buildings owned by } \\
\text { municipality by } 10 \% \text { (base year 2014) } \\
\text { 3. To encourage reduction in energy consumption in } \\
\text { residential sector by } 5 \% \\
\text { 4. Reduce electricity consumption by } 5 \% \text { for public lighting } \\
\text { (base year } 2015 \text { ) } \\
\text { 5. Reduce electricity consumption by } 5 \% \text { for public transport } \\
\text { (base year 2015) }\end{array}$ \\
\hline Medium & $\mathrm{C}$ & 20 & 2020 & 2008 & - \\
\hline Medium & D & 20 & 2020 & 2000 & - \\
\hline Small & $\mathrm{E}$ & 40 & 2020 & 2010 & $\begin{array}{l}\text { 1. Reduce } \mathrm{CO}_{2} \text { emissions by } 45 \% \text { until } 2030 \\
\text { 2. Reduce energy consumption in buildings owned by } \\
\text { municipality by } 10 \% \\
\text { 3. To encourage reduction in energy consumption in } \\
\text { residential sector by } 5 \% \\
\text { 4. Reduce energy consumption in energy production sector } \\
\text { (base year 2014) }\end{array}$ \\
\hline Small & $\mathrm{F}$ & 10 & 2020 & 2012 & $\begin{array}{l}\text { 1. Reduce } \mathrm{CO}_{2} \text { emissions by } 30 \% \text { until } 2030 \\
\text { 2. Reduce energy consumption in buildings owned by } \\
\text { municipality by } 10 \% \\
\text { 3. To encourage reduction in energy consumption in } \\
\text { residential sector by } 5 \% \\
4 \text {. Reduce energy consumption in energy production sector } \\
\text { by } 5 \% \text { (base year 2015) }\end{array}$ \\
\hline Small & G & 20 & 2020 & 2010 & $\begin{array}{l}\text { 1. Reduce energy consumption in buildings owned by } \\
\text { municipality by } 5 \% \text { (base year 2014) } \\
2 . \text { To encourage reduction in energy consumption in } \\
\text { residential sector by } 5 \% \\
3 \text {. Reduce energy consumption in energy production sector } \\
\text { by } 5 \% \text { (base year } 2012 \text { ) }\end{array}$ \\
\hline Small & $\mathrm{H}$ & 40 & 2020 & 2008 & $\begin{array}{l}\text { 1. Reduce energy consumption in buildings owned by } \\
\text { municipality by } 20 \% \\
2 . \text { To encourage reduction in energy consumption in } \\
\text { residential sector by } 10 \% \text { (base year 2014) }\end{array}$ \\
\hline Small & $\mathrm{J}$ & 20 & 2020 & 2010 & - \\
\hline Small & $\mathrm{K}$ & 20 & 2025 & 2016 & $\begin{array}{l}\text { 1. Reduce energy consumption in buildings owned by } \\
\text { municipality by } 10 \% \text { (base year 2016) } \\
2 . \text { To encourage reduction in energy consumption in } \\
\text { residential sector by } 5 \% \\
3 \text {. Reduce energy consumption in energy production sector } \\
\text { by } 5 \% \text { (base year } 2016 \text { ) }\end{array}$ \\
\hline $\begin{array}{l}\text { Very } \\
\text { small }\end{array}$ & $\mathrm{L}$ & 20 & 2020 & 2007 & - \\
\hline
\end{tabular}




\subsection{Data Availability at Municipalities}

The most significant areas where feedback about data availability in the municipal level were requested:

- $\mathrm{CO}_{2}$ inventory;

- Energy consumption data;

- Data of energy costs.

Six (2 large, 4 small) out of eleven municipalities have compiled a $\mathrm{CO}_{2}$ or GHG-inventory, five of which noted that they do it on a regular basis. During the survey participants were also asked (subjectively - 1 very important, 3 - moderately, 5 - not important) to rate how important the inventory is for development and implementation of SEAP measures. Answers varied significantly. While only two municipalities assessed $\mathrm{CO}_{2}$ or GHG-inventory as very important, most rated it as moderately important. Municipalities without inventories rated this aspect from 1-3 (1 very important, 3 - moderately, 5 - not important), but municipalities that have compiled inventories gave rates from $1-5$.

In order to assess energy data availability, municipalities were asked what kind of data they collect and how often. It seems that this is still an important issue as two municipalities (medium and very small) do not collect any data about public buildings. Four municipalities collect data for each building separately, three municipalities collect aggregated data for several buildings, and in two municipalities energy data are collected separately, but for some aggregated.

Half of the municipalities collect energy data and energy costs, however the other half only energy consumption data. In four municipalities data is collected by direct meter readings, and in other four digital transmissions (smart meters) of data is used, one municipality pointed out that they use a different technology. All municipalities collect monthly data except for one municipality which collects data annually.

Municipalities were also asked to comment on the main challenges concerning the generation and collection of energy-relevant data in the public sector. Most comments were about the human factor - responsible persons make mistakes, forget, miss deadlines. Also, many procedural issues were mentioned, like collection of data is forgotten because of lack of procedure in cases of sick leave or other issues, no common methodology for collection of data, etc.

\subsection{SEAP Implementation}

To understand what commitments municipalities are ready to take for implementing the SEAP, questions about the human resources and financial resources dedicated for the SEAP were asked. It is expected that better results will have at the municipalities with more personnel involved, and more financial resources dedicated for SEAP activities.

As Table 3 shows, all municipalities except D, have officially delegated responsibility to implement SEAP to some department or administrative body, but the level of position responsible for it vary significantly. While most of municipalities have assigned a responsibility to a department or a director of department, for two municipalities executive directors are responsible, which can indicate a lack of responsibilities at the everyday management level. From five respondents that gave answer about a number of people responsible for SEAP implementation, one municipality $(\mathrm{G})$ has assigned responsibilities to ten persons, other four $(A ; C ; J ; K)$ municipalities have one person. Some activities that have been supported by expert organizations are used. Municipalities pointed out that support from experts were used for developing SEAPS and energy audits, finding solutions for improving energy efficiency in buildings etc. 
TABLE 3. RESPONSIBILITIES AND FUNDING FOR SEAP IMPLEMENTATION

\begin{tabular}{|c|c|c|c|c|c|}
\hline \multicolumn{2}{|c|}{ Municipality } & $\begin{array}{l}\text { What department or } \\
\text { administrative body is } \\
\text { responsible for the } \\
\text { implementation of the } \\
\text { SEAP/SECAP in your } \\
\text { Local Authority? }\end{array}$ & $\begin{array}{l}\text { Could you please } \\
\text { estimate the number } \\
\text { of staff being } \\
\text { responsible for the } \\
\text { implementation of } \\
\text { the SEAP/SECAP? }\end{array}$ & $\begin{array}{l}\text { Could you please } \\
\text { estimate the share of } \\
\text { labour costs of the staff } \\
\text { responsible for the } \\
\text { implementation of the } \\
\text { SEAP/SECAP funded } \\
\text { by third party funds? }\end{array}$ & $\begin{array}{l}\text { For which tasks are } \\
\text { external consultants and } \\
\text { research institutions } \\
\text { predominantly involved } \\
\text { (if at all)? }\end{array}$ \\
\hline A & Large & $\begin{array}{l}\text { Deputy Executive } \\
\text { Director (regarding } \\
\text { properties) }\end{array}$ & 1 & $0 \%$ & $\begin{array}{l}\text { Mostly the Department } \\
\text { of Development is } \\
\text { working with SEAP } \\
\text { issues. For some } \\
\text { specific tasks external } \\
\text { consultants are hired, } \\
\text { like local University }\end{array}$ \\
\hline B & Large & $\begin{array}{l}\text { City Council, } \\
\text { Department of } \\
\text { Development }\end{array}$ & & $0 \%$ & $\begin{array}{l}\text { Experts are involved for } \\
\text { performing energy } \\
\text { audits, for certification } \\
\text { of energy management } \\
\text { system and development } \\
\text { of planning documents }\end{array}$ \\
\hline $\mathrm{C}$ & Medium & $\begin{array}{l}\text { Infrastructure } \\
\text { development } \\
\text { department }\end{array}$ & 1 & $0 \%$ & - \\
\hline $\mathrm{D}$ & Medium & - & & - & - \\
\hline $\mathrm{E}$ & Small & Energy manager & & - & - \\
\hline $\mathrm{F}$ & Small & $\begin{array}{l}\text { Deputy Executive } \\
\text { Director (regarding } \\
\text { properties and } \\
\text { environment) }\end{array}$ & & $0 \%$ & $\begin{array}{l}\text { Consultations from state } \\
\text { owned financial } \\
\text { institution "Altum" } \\
\text { about insulation projects } \\
\text { of multi-apartment } \\
\text { houses }\end{array}$ \\
\hline G & Small & Executive Director & 10 & $1-10 \%$ & - \\
\hline $\mathrm{H}$ & Small & $\begin{array}{l}\text { Technical project } \\
\text { manager of department } \\
\text { of economic activities }\end{array}$ & & $11-25 \%$ & $\begin{array}{l}\text { Municipality is a partner } \\
\text { in the "Life Adaptate" } \\
\text { project, during which } \\
\text { development of SECAP } \\
\text { (sustainable energy and } \\
\text { climate action plan) is } \\
\text { planned }\end{array}$ \\
\hline $\mathrm{J}$ & Small & Executive Director & 1 & $0 \%$ & - \\
\hline $\mathrm{K}$ & Small & $\begin{array}{l}\text { Department of } \\
\text { planning and } \\
\text { development }\end{array}$ & 1 & $76-100 \%$ & - \\
\hline $\mathrm{L}$ & $\begin{array}{l}\text { Very } \\
\text { small }\end{array}$ & SEAP working group & & $0 \%$ & $\begin{array}{l}\text { The external consultants } \\
\text { are involved in finding } \\
\text { solutions for } \\
\text { improvement of } \\
\text { municipal building } \\
\text { energy efficiency, to } \\
\text { perform the energy audit } \\
\text { and do research on the } \\
\text { initial situation }\end{array}$ \\
\hline
\end{tabular}


Only one municipality (municipality B) from all questioned municipalities was able to specify allocated budget for SEAP implementation, others gave only an estimate. It is worth noting, for municipality B $67 \%$ of all budget for SEAP was planned to be covered by EU funds and only $9 \%$ by a municipal budget. Other municipalities explained that annual municipal budget is not coordinated within SEAP, but instead within a local development plan. However, some activities overlap also with SEAP activities, so in many cases implementation of SEAP is a side effect from the municipal budget standpoint. Other municipalities also commented that a lot of third-party funding is used for investments in bigger infrastructure projects.

Ten out of eleven municipalities have established a working group dedicated to SEAP implementation. However, meeting frequency of working groups is rather low: in two municipalities ( $\mathrm{B}$ and $\mathrm{G}$ ), the energy team meets once a year, at municipality $\mathrm{H}$ meetings are organised on a quarterly basis. Others noted meetings are not regular but based on necessity. Municipality $\mathrm{C}$, has not established an energy team, however they have established two separate working groups. One targets energy efficiency in multi-apartment buildings whereas the second one focus on other climate and energy issues.

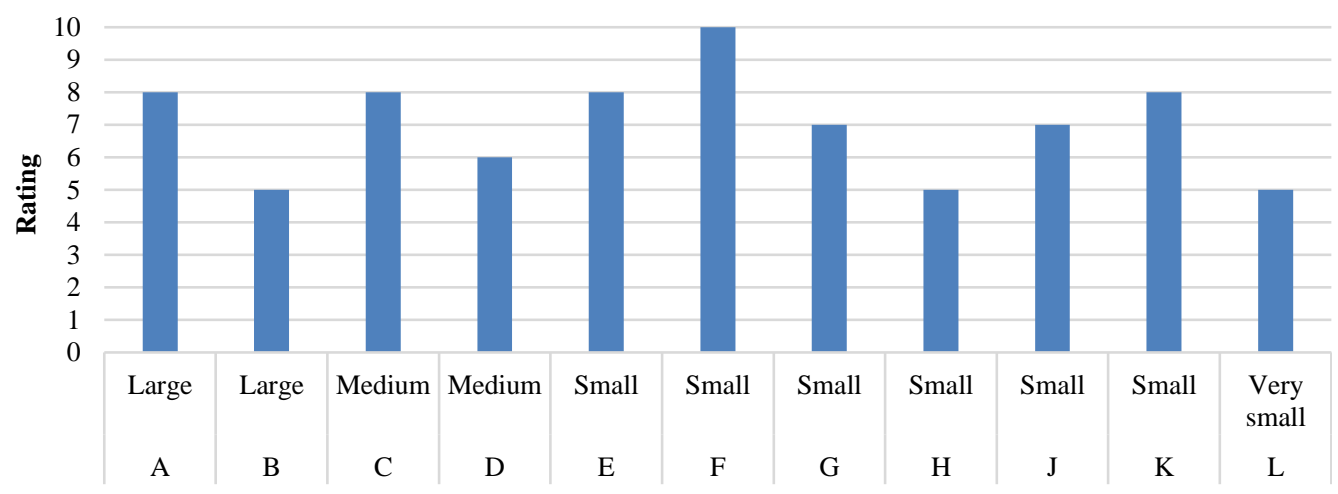

Fig. 2. Ratings of political support for implementing climate and energy related measures from 1 (lowest) to 10 (highest).

Municipalities were asked to rate the political support on a scale from 1 to 10. As Fig. 2 shows, municipalities identify that political support is from 5 to 10 . Such results could be closely related to the budget dedicated for SEAP implementation, but not only. Municipality F has noted that climate and energy issues are integrated within daily routines of all municipal departments and are not budgeted or analysed separately. This makes it hard to assess if high political support is backed up by substantial actions. While municipality B rate political support for climate and energy issues only with 5, they were the only ones able to provide information on the budget of the implemented measures. They also commented that municipality should involve more specialists for implementing energy management system, invest more in smart solutions for data collection and energy saving and dedicate more resources for organizing energy saving campaigns. Municipality A remarked that capacity of one person is not enough for managing the whole energy sector. Municipalities G, H, J noted that there are not enough investments made in the energy sector, and that there are restrictions for municipalities to take long term loans, which reduces the ability for municipalities to conduct larger investments. Municipalities D, L mostly commented about the lack of proper communication between municipal departments, and the lack of awareness among municipal employees about energy and climate targets.

Municipalities were asked to list three main activities of their SEAPs, see Table 4. 
TABLE 4. MAIN ACTIVITIES INCLUDED AT SEAPS

\begin{tabular}{|c|c|c|c|c|}
\hline \multicolumn{2}{|c|}{ Municipality } & \multirow{2}{*}{$\begin{array}{l}\text { Action A } \\
\text { To establish data online } \\
\text { management and } \\
\text { monitoring system }\end{array}$} & \multirow{2}{*}{$\begin{array}{l}\text { Action B } \\
\text { Renovation projects for all schools. } \\
\text { At some schools it includes energy } \\
\text { efficiency measures - automatic } \\
\text { control or radiators, new ventilation } \\
\text { solutions }\end{array}$} & \multirow{2}{*}{$\begin{array}{l}\text { Action C } \\
\begin{array}{l}\text { Renovation projects of } \\
\text { particular buildings }\end{array}\end{array}$} \\
\hline A & Large & & & \\
\hline B & Large & $\begin{array}{l}\text { Energy efficiency measures } \\
\text { at buildings funded by } \\
\text { ERDF }\end{array}$ & $\begin{array}{l}\text { Modernization of tram } \\
\text { infrastructure }\end{array}$ & $\begin{array}{l}\text { To expand public lighting } \\
\text { and renovate existing one, } \\
\text { funded by municipal budget }\end{array}$ \\
\hline $\mathrm{C}$ & Medium & $\begin{array}{l}\text { To increase energy } \\
\text { efficiency of public } \\
\text { buildings }\end{array}$ & $\begin{array}{l}\text { To build boiler house powered by } \\
\text { wood chips }\end{array}$ & $\begin{array}{l}\text { Energy efficiency measures at } \\
\text { apartment buildings. ("Labs } \\
\text { nams" Ltd. has been created to } \\
\text { support the process) }\end{array}$ \\
\hline $\mathrm{D}$ & Medium & $\begin{array}{l}\text { The renovation of preschool } \\
\text { educational institution } \\
\text { "Pasacina" is in progress, of } \\
\text { "Pepija" has been finished }\end{array}$ & $\begin{array}{l}\text { Transportation sector }-2 \text { electrical } \\
\text { cars bought in } 2016\end{array}$ & $\begin{array}{l}\text { Construction of heating and } \\
\text { water supply for two streets, } \\
\text { construction of new heat } \\
\text { pipes to connect three new } \\
\text { streets to existing district } \\
\text { heating network }\end{array}$ \\
\hline $\mathrm{E}$ & Small & - & - & - \\
\hline $\mathrm{F}$ & Small & $\begin{array}{l}\text { Energy efficiency project of } \\
\text { municipalities New castle } \\
\text { (cultural heritage) and } \\
\text { energy efficiency project of } \\
\text { culture centre, financed by } \\
\text { third-party funding }\end{array}$ & $\begin{array}{l}\text { Development of energy-efficient } \\
\text { requirements for procurement of } \\
\text { new vehicles }\end{array}$ & $\begin{array}{l}\text { Energy efficiency project of } \\
\text { elementary school (project } \\
\text { finished in 2017) }\end{array}$ \\
\hline $\mathrm{G}$ & Small & $\begin{array}{l}\text { To introduce Energy } \\
\text { Performance Contracting } \\
\text { principles, for renovation } \\
\text { projects }\end{array}$ & & \\
\hline $\mathrm{H}$ & Small & $\begin{array}{l}\text { To collect and analyse } \\
\text { energy data }\end{array}$ & $\begin{array}{l}\text { To replace existing municipal fleet with } \\
\text { new, more energy-efficient vehicles }\end{array}$ & $\begin{array}{l}\text { Replace street lights with } \\
\text { more efficient ones }\end{array}$ \\
\hline $\mathrm{J}$ & Small & $\begin{array}{l}\text { Renovation and insulation } \\
\text { of municipal buildings }\end{array}$ & $\begin{array}{l}\text { Partly to change public lighting } \\
\text { bulbs to LED }\end{array}$ & $\begin{array}{l}\text { Procurement of } 2 \text { electric } \\
\text { automobiles }\end{array}$ \\
\hline $\mathrm{K}$ & Small & $\begin{array}{l}\text { The Energy action plan 2018- } \\
2025 \text { has been developed }\end{array}$ & $\begin{array}{l}\text { The energy management system } \\
\text { working group is established }\end{array}$ & \\
\hline $\mathrm{L}$ & $\begin{array}{l}\text { Very } \\
\text { small }\end{array}$ & - & - & - \\
\hline
\end{tabular}

The main activities included in SEAPs mostly included renovation projects for municipal buildings or public lighting. This shows that municipalities deeply focus on municipal infrastructure instead of including different sectors. Some municipalities like, A, H, K, only starts to analyse and properly collect data, which could lead to better decisions in the future. Municipalities J, B and D are the only ones who declared actions related to the transport sector. Even though municipalities tend to include measures only related to their own infrastructure, many of them indicate lack of financial resources. Most importantly, municipality D indicated the risk of low-quality energy audits and low quality renovation projects, which can cause lower energy savings resulting in low efficient investment. Miezis et al. has also highlighted the problem with low quality construction works in Latvia, that reduces trust in renovation projects and potential energy savings [14]. 


\subsection{Monitoring and Energy Management System}

Monitoring is an essential part of energy management. Only two municipalities $\mathrm{C}$ and L answered negatively on the question about whether the local authority monitors the state of implementation and/or impacts of measures. Municipalities B, E, H, K, and D only monitor implementation of SEAP, but implementation and impact of measures or activities are monitored at municipalities A, F, G, and J.

From 11 only three municipalities do not have any experience with the design and implementation of an energy management system. Municipal councils of all small and large municipalities have adopted a resolution about the adoption of energy management and have an energy manager in place, from which six have developed an energy management manual and five (both large - A; B; and small - F; G; H) have an energy management system in place.

For municipalities $\mathrm{A}$ and $\mathrm{B}$, implementation of a certified energy management system (EnMS) is required by the Energy Efficiency Law. A number of municipalities (with population above 10000 and territory development index above 0.5 (development index is generalised indicator, based on eight different statistical indicators)) are required to implement EnMS, however they are not obliged to certify. For other municipalities development, implementation and certification of EnMS is voluntary. According to survey results, five municipalities have not implemented EnMS despite the legal requirements.

Scope and boundaries of the EnMS vary among five municipalities. It should be noted that all municipalities with the EnMS in place, have organized informative campaigns concerning energy management activities and all of them do $\mathrm{CO}_{2}$ or GHG inventory on a regular basis. As boundaries of the EnMS vary among municipalities and in most of the municipalities EnMS has only recently been introduced, it is hard to assess the impact of the EnMS on the overall implementation of the SEAPs compared to municipalities without EnMS in place. More analysis on long term and short term gains from EnMS is required.

\section{Discussion ANd CONCLUSIONS}

Implementation of SEAPs has been analysed in 11 different Latvian municipalities. Results show that most of the municipalities still struggle a lot with reaching their energy and climate goals, although municipalities in Latvia tend to be very cautious with commitment towards high energy and climate targets. They all have a $\mathrm{CO}_{2}$ reduction goal, as it is the main reason for developing SEAP at all, but by analysing sector-specific goals it is not clear whether local authorities have identified which sectors are the most important in reducing $\mathrm{CO}_{2}$, and whether they understand how the $\mathrm{CO}_{2}$ target could be reached. Also, all municipalities set higher goals for sectors they have full control, like energy efficiency in municipal buildings. But when it comes to the private sector, local authorities avoid taking any responsibility of energy consumption trends and set very low targets. This can be due to a lack of knowledge and understanding how to influence and support change of behaviour in their communities. Also, it could be explained by the lack of involvement of stakeholders at target setting phase and selection of the measures. Gustafsson et al. already highlighted the issue of unwillingness to adopt and implement strategies, when municipalities exclude important stakeholders from target setting process, resulting in targets which municipalities do not have a control of, or not setting a targets at all [15]. In some cases, there is evidence that when the development of SEAP is heavily supported by external experts, there is no real motivation inside the municipality to adopt the strategy which leads to the opinion that a lack of funding is what keeps them from reaching their goals. Most of the studied municipalities could not distinguish how much financial resources is used for SEAP activities and for most of them there is no specific budget for it. SEAP implementation is seen as a side effect from 
the municipal budget point of view, and only activities that overlap or can be easily integrated in activities of local development plan are conducted. Implementation of other activities is considered only when external funding is available. As the analysis highlighted in a few examples (struggle with data collection, data analysis) municipalities lack qualified personnel for energy management. This contributes to the fact that some municipalities analyse only realized measures, but not their impact on the amount of greenhouse gas emissions.

This research has led to the conclusion that municipalities lack knowledge how to set responsibilities and procedures to create the continuity of SEAP in their daily processes. In small rural municipalities, short-term project-based external support from experts does not solve the knowledge deficiency in the long-term. To meet ambitious climate and energy goals in the rural regions of Latvia, comprehensive and affordable tool should be developed for municipalities to enable them to control their energy consumption and most importantly, to enable them to understand the data for acting accordingly. One of such is systematic energy management, however further in-depth research should be done in order to analyse the full effect of SEAP and EnMS implementation on long-term energy performance.

\section{ACKNOWLEDGEMENT}

This project has received funding from the European Union's Horizon 2020 research and innovation program under grant agreement No 754162. The sole responsibility for the content of this article lies with the Compete4SECAP project and does not necessarily reflect the opinion of the European Union.

\section{REFERENCES}

[1] Helm D. The European framework for energy and climate policies. Energy Policy 2014:64:29-35. doi:10.1016/j.enpol.2013.05.063

[2] UN General Assembly. UN adopts new Global Goals, charting sustainable development for people and planet by 2030. Department of Economic and Social Affairs, 2015.

[3] Horowitz C. A. Paris Agreement. American Society of International Law 2016:55(4):740-755. doi: $10.1017 / \mathrm{s} 0020782900004253$

[4] European Commission. A Clean Planet for all A European strategic long-term vision for a prosperous, modern, competitive and climate neutral economy. European Commission Directorate-General for Climate Action, 2018.

[5] Bocquier P. World Urbanization Prospects: An Alternative to the UN Model of Projection Compatible with the Mobility Transition Theory. Demographic Research 2014:12(9):197-236. doi:10.4054/DemRes.2005.12.9

[6] Petersen J. P. The application of municipal renewable energy policies at community level in Denmark: A taxonomy of implementation challenges. Sustainable Cities and Society 2018:38:205-218. doi:10.1016/j.scs.2017.12.029

[7] Latosov E., Volkova A., Siirde A., Kurnitski J., Thalfeldt, M. Methodological approach to determining the effect of parallel energy consumption on district heating system. Environmental and Climate Technologies 2017:19:15-14. doi:10.1515/rtuect-2017-0001

[8] Bariss U., Bazbauers G., Blumberga A., Blumberga D. System Dynamics Modeling of Households' Electricity Consumption and Cost-Income Ratio: a Case Study of Latvia. Environmental and Climate Technologies 2017:20:36-50. doi:10.1515/rtuect-2017-0009

[9] Pablo-Romero M. P., Sánchez-Braza A., González-Limón M. J. Covenant of Mayors: Reasons for Being an Environmentally and Energy Friendly Municipality. Review of Policy Research 2015:32(5):576-599. doi:10.1111/ropr.12135

[10] Covenant of Mayors. Covenant of Mayors Annual report, 2018.

[11] Melica G., Bertoldi P., Kona A., Iancu A., Rivas S., Zancanella P. Multilevel governance of sustainable energy policies: The role of regions and provinces to support the participation of small local authorities in the Covenant of Mayors. Sustainable Cities and Society 2018:39:729-739. doi:10.1016/j.scs.2018.01.013

[12] Ivner J., Gustafsson S. Follow-Up of Local Energy and Climate Strategies - A Study of Six Small Swedish Municipalities. Linkoping: Linkoping University Electronic Press, 2011:57:2362-2369. doi:10.3384/ecp110572362

[13] Kamenders A., Rosa M., Kass K. Low carbon municipalities. The impact of energy management on climate mitigation at local scale. Energy Procedia 2017:128:172-178. doi:10.1016/j.egypro.2017.09.038

[14] Miezis M., Zvaigznitis K., Stancioff N., Soeftestad L. Climate Change and Buildings Energy Efficiency - the Key Role of Residents. Environmental and Climate Technologies 2016:17:30-43. https://doi.org/10.1515/rtuect-2016-0004

[15] Gustafsson S., Ivner J., Palm J. Management and stakeholder participation in local strategic energy planning Examples from Sweden. Journal of Cleaner Production 2015:98:205-212. doi:10.1016/j.jclepro.2014.08.014 